\section{Pathologic findings and clinical outcome in patients undergoing retroperitoneal lymphadenectomy after multiple chemorherapy regimens for metastatic nonseminomatous testicular tumors}

\author{
Djordje M. Argirovic ${ }^{1,3}$, Aleksandar Dj. Argirovic ${ }^{2}$ \\ ${ }^{1}$ Division of Urological Chemotherapy, Clinic of Urology, \\ Clinical Center of Serbia, Belgrade \\ ${ }^{2}$ Outpatient Clinic ,Argirovic“, Belgrade, \\ ${ }^{3}$ Department of Urology, Clinical hospital center Zemun, Belgrade
}

\section{Patološki nalaz i klinički tok kod pacijenata sa metastazama neseminomskih testikularnih tumora kod kojih je primenjena retroperitonealna limfadenektomija posle multiplih hemoterapija}

\author{
Đordje M. Argirović1,3, Aleksandar Đ. Argirović ${ }^{2}$ \\ ${ }^{1}$ Urološka klinika, Klinički Centar Srbije “, Beograd \\ ${ }^{2}$ Urološka služba, Kliničko Bolnički Centar Zemun, \\ Beograd \\ ${ }^{3}$ Poliklinika "Argirović, Beograd
}

\section{Apstrakt}

We reviewed our experience with retroperitoneal lymphadenectomy (RPLA) after multiple cisplatin-based chemotherapy regimens in nonseminomatous testicular tumors (NSTT) patients and specifically evaluated clinicopathologic and treatment trend in addition to potential predictors of survival. Fort-one patients with NSTT underwent their RPLA between 1982 and 2005 after $\geq 2$ regimens of chemotherapy. Thirteen patients $(32 \%)$ necessitate redo-RPLA, combined with nephrectomy in 6 patients. 13 extra-RP (ERP) resections were performed in 11 patients (27\%), including pulmonary (7), neck (4) and liver (2) sites. Thirty patients (73\%) are rendered free of disease and $26(63 \%)$ obtained serologic remission. Nine patients who relapse, necessitated new salvage chemotherapy+surgery (3 teratoma, 6 vital carcinoma [VC]). Four of 9 relapsing patients (44\%) are currently free of disease with redoRPLA. Alive, free of disease are 19 pts (46\%) at median follow-up of 131 months. Study of RP pathology demonstrated the presence of fibrosis in $15 \%$, teratoma in $39 \%$ and $\mathrm{VC}$ in $46 \%$, with survival in $67 \%, 56 \%$ and $32 \%$, respectively. Different histology occurre in 38\% at redo-RPLA and in $64 \%$ at ERP resection in comparison to previous RP pathology. Univariate analysis of clinicopathologic parameters associated with VC at RPLA included RP masses $\geq 5 \mathrm{~cm}(p<0.05)$, elevated AFP $(p<0.001)$ or HCG $(p<0.05)$ and ERP resection $(p<0.04)$. On univariate analysis survival was worse in patients with RP masses $\geq 5 \mathrm{~cm}(\mathrm{p}<0.04)$, elevated AFP $(\mathrm{p}<0.05)$ or HCG $(p<0.007)$, ERP resection $(p<0.01)$ and $\mathrm{VC}$ $(p<0.004)$. On multivariable analysis, a RP masses $\geq$ $5 \mathrm{~cm}(\mathrm{p}<0.03)$ and $\mathrm{VC}(\mathrm{p}<0.005)$ predicted a worse
Napravljen je pregled iskustva sa retroperitonealnom limfadenektomija (RPLA), a posle brojnih hemioterapijskih ciklusa na bazi cisplatine kod pacijenata sa neseminomskim tumorima testis (NSTT) i posebno evaluirani kliničko patološki i terapeutski trendovi kao dodatak potencijalnim pokazateljima preživljavanja. 41 pacijent sa NSTT su podvrgnuti RPLA izmedju 1982.-2005. posle $\geq 2$ hemioterapijskih protokola. 13 pacijenata ( $32 \%$ ) je iziskivalo ponovnu RPLA, kombinovanu sa nefrektomijom kod 6 pacijenata. 13 ekstraretroperitonealnih resekcija je učinjeno kod 11 pacijenata (27\%) uključujući pulmonalne (7), vratne (4) i jetrine (2) lokalizacije. 30 pacijenata $(73 \%)$ je prevedeno u kompletnu remisiju dok je 26 (63\%) imalo serološku remisiju. 9 pacijenata (32\%) je imalo recidiv iziskujući novu selvage hemioterapiju i hirurgij (3 teratoma, 6 vitalni karcinom). 4 od 9 pacijenata $(44 \%)$ sa recidivom je bilo bez znakova bolesti posle ponovne RPLA. Živo i bez znakova bolesti je 19 pacijenata (46\%) za srednje praćenje od 131 meseca. Retroperitonealna histološka analiza je pokazala prisustvo fibroze kod 15\%, teratoma kod 39\% I vitalnog karcinom kod $46 \%$, sa preživljavanjem kod $67 \%, 56 \%$, $32 \%$ respektivno. Različita histopatologija je postojala kod 38\% na ponovnoj RPLA i kod 64\% na ekstraretroperitonealnoj resekciji u odnosu na raniju retroperitonealnu histologiju. Nivarijantna analiza kliničko patoloških parametara udruženih sa vitalnim karcinomom na RPLA je pokazala da su samostalni prediktivni faktori retroperitonealna masa preko $5 \mathrm{~cm}(\mathrm{p}<0.04)$, povišeni AFP $(p<0.001)$ ili HCG $(\mathrm{p}<0.005)$ i ekstraretroperitonealna resekcija $(\mathrm{p}<0.04)$. Na multivarijantnoj anali$\mathrm{zi}$, retroperitonealna masa preko $5 \mathrm{~cm}(\mathrm{p}<0.03)$ i vitalni karcinom $(p<0.005)$ su značili lošu prognozu. Naša 
prognosis. Our data support the continued use of salvage RPLA in three separated groups of patients: 1. Patients who achieved a complete response (CR) to $2^{\text {nd }}$-line chemotherapy and have no radiologic evidence of disease should undergo RPLA; 2. Patients who achieved a partial response (PR) to chemotherapy should undergo RPLA with ERP surgery, as indicated; 3. Highly selected group of patients with residual masses and elevated serum tumor markers (STM), particularly AFP, after chemotherapy may be candidate for surgery.

Key words: retroperitoneal lymphadenectomy, salvage therapy, chemotherapy, nonseminomatous testicular tumors, metastatic. studija podržava kontinuiranu primenu primenu salvage RPLA kod 3 separatne grupe pacijenata : (1) pacijenti koji postignu kompletnu remisiju na drugu liniju hemioterapije I nemaju radiološke znake za prisustvo rezidualne bolesti moraju biti podvrgnuti RPLA; (2) pacijenti koji postignu parcijalnu remisiju posle hemioterapije moraju imati RPLA, sa ekstraretroperitonealnom hirurgijom ukoliko je indikovano; (3) Strogo selekcioniran grupa pacijanata sa rezidualnom masom i povišenim vrednostima tumorskih markera, posebno AFP, posle hemioterapije mogu biti kandidati za hirurgiju.

Ključne reči: Retroperitonealna limfadenektomija, salvage terapije, hemioterapija, neseminomski tumori testis, metastatski.

\section{Introduction}

Induction chemotherapy is the initial treatment for men with clinical stage IIA/B or C NSTT or patients with elevated STM. Approximately $20 \%$ to $30 \%$ of patients experience disease progression or recurrence and that require salvage chemotherapy ${ }^{1}$. Depending on their risk profile, from $35 \%$ to $70 \%$ of these patients will achieve a CR to ifosfamide and cisplatin -based regimens ${ }^{2,3,4}$. Patients with disease amenable to surgery are candidates for RPLA in addition to resection of any ERP disease. Disease progression during $2^{\text {nd }}$ - line therapy or subsequent recurrence portends very poor prognosis.

Relatively few contemporary data exist on RPLA after multiple regimens of chemotherapy. When RPLA is performed in this setting, it has been reported that VC occurs in approximately $50 \%$ of patients ${ }^{5,6,7}$. Because of the high proportion of men with VC or teratoma after salvage chemotherapy, surgical resection of all disease sites is attempted when feasible. The objectives of the current study were to review our experience with RPLA after multiple cisplatin-based chemotherapy regimens and specifically evaluate the clinicopathologic and treatment trends in addition to potential predictors of survival.

\section{Material and methods}

Forty-one patients with metastatic NSTT underwent their RPLA after $>2$ regimens of chemotherapy between 1982 and 2005. At initial diagnosis, patients were classified as good, intermediate, or poor risk according to the International Germ Cell Consensus Classification Group (IGCCCG) ${ }^{8}$. In majority of patients $1^{\text {st }}$-line chemotherapy included PVB (platinum, vinblastine, bleomycin)/PEB (platinum, etoposide, bleomycin) regimen and $2^{\text {nd }}$-line according to PVI (platinum,vinblastine, ifosfamide)/PVE (platinum, vinblastine, etoposide) regimen. After each chemotherapy regimen, STM levels were obtained, x-ray of the lung, ultrasound and computed tomography (CT) of the abdomen and minor pelvis were performed to assess tumor response. STM elevation was defined as an AFP level $>6.65 \mathrm{ng} / \mathrm{ml}$ or a HCG level $>2.25 \mathrm{mIU} / \mathrm{ml}$ that did not decline according to its serum half-life. Lymph node size before and after chemotherapy was determined by measuring the greatest transverse dimension of the largest mass on CT imaging. In patients with normalized STM levels, an RPLA and surgical resection of all ERP residual masses were recommended when feasible. The patients with finding of fibrosis and teratoma are only strictly followed-up without further therapy, whereas the patients with VC received $3^{\text {rd }}$-line chemotherapy. Preoperatively, it was believed that all 41 patients had disease that was amenable to complete surgical resection. 
The chi-square test for independence, with Yates correction when necessary, was used to compare time-specific trends and histological findings at RPLA. Univariate predictors of VC or disease-specific survival (DSS) from the time of RPLA were analyzed by using the Kaplan-Meier method and log-rank test. A Cox proportional hazards regression model that included all variables with a $\mathrm{P}$ values $<0.05$ on univariate analysis was built to predict DSS. All statistical analysis where performed using SPSS (version 17.0; SPSS Inc., Chicago, Il., JUSA).

\section{Results}

Patients characteristics prior to RPLA are summarized in Table 1. and 2.The initial histopathological diagnosis of the primary testicular tumor was obtained after radical orchiectomy. Prior to $2^{\text {nd }}$-line chemotherapy, 32 patients $(78 \%)$ failed to achieve CR to $1^{\text {st }}$-line treatment and $9(22 \%)$ had achieved CR followed by disease recurrence. All patients underwent postchemotherapy-RPLA (incomplete in 7 patients), whereas 13 patients (32\%) necessitate redo-RPLA (accompained with nephrectomy in 6 patients). Initially, 13 ERP resections were performed in 11 patients (27\%) including pulmonary (7), neck (4) and liver (2) sites.

Mean age at diagnosis was 28.8 years. Initially, $72 \%$ patients had far advanced metastatic disease, $68 \%$ had teratoma compound in the primary testicular tumor, indication for $2^{\text {nd }}$-line chemotherapy was mainly residual disease (57\%), 90\% patients received previously at least 2 chemotherapeutical regimens, $73 \%$ have bulky abdominal disease $\geq 5 \mathrm{~cm}$ in diameter and $68 \%$ patients were classified to be intermediate/poor IGCCCG risk group. At RPLA, 32\% had elevated AFP and 15\% had elevated HCG. RP mass pre-induction chemotherapy and pre-RPLA were $5.9+/-4.2$ and $4.9+/-5.1 \mathrm{~cm}$ in diameter, respectively.

\begin{tabular}{|l|l|}
\hline Characteristics & No. of patients (\%) \\
\hline$\underline{\text { Age, years }}$ & \\
\hline Mean \pm SD & $28.8 \pm 3.6$ \\
\hline Range & $16-52$ \\
\hline Initial clinical stage & \\
\hline I & $7(18)$ \\
\hline IIA/IIB & $4(10)$ \\
\hline IIC & $9(20)$ \\
\hline III & $21(52)$ \\
\hline Histology and initial diagnosis & \\
\hline With teratoma compound & $28(68)$ \\
\hline Without teratoma compound & $13(32)$ \\
\hline Indication for 2nd line chemotherapy & \\
\hline Disease progression & $8(19)$ \\
\hline Disease recurrence & $10(24)$ \\
\hline Residual disease & $23(57)$ \\
\hline No. of chemotherapy regimens before RPLA & \\
\hline 2 & $37(90)$ \\
\hline$>2$ & $4(10)$ \\
\hline$\underline{\text { Retroperitoneal mass pre-RPLA }}$ & \\
\hline$<5$ cm & $11(27)$ \\
\hline$\geq 5$ cm & $30(73)$ \\
\hline
\end{tabular}

Table 1. Characteristics of patinetnts before salvage RPLA 


\begin{tabular}{|l|c|}
$\begin{array}{l}\text { CHARACTERISTICS/REGIMENS } \\
\text { IGCCCG at iduction chemotherapy }\end{array}$ \\
\hline Good & $13(32)$ \\
\hline Intermediate/poor & $28(68)$ \\
\hline First chemotherapy regimen (n=41) & $15(42)$ \\
\hline PVB & $18(34)$ \\
\hline PEB & $1(3)$ \\
\hline PE & $6(18)$ \\
\hline HD PVBE & $1(3)$ \\
\hline HDPEB & \\
\hline Second chemotherapy regimen (n=48) & $32(68)$ \\
\hline PVI & $9(18)$ \\
\hline PVE & $1(2)$ \\
\hline PE & $3(6)$ \\
\hline VAB -6 & $3(6)$ \\
\hline CARBOPEC & $5.9 \pm 4.2$ \\
\hline RP mass preinducation chemotherapy (mean \pm SD) $\mathbf{c m}$ & $4.9 \pm 5.1$ \\
\hline RP mass pre-RPLA(mean \pm SD) $\mathbf{c m}$ & \\
\hline Elevated serum tumor markers at RPLA & $13(32)$ \\
\hline AFP & $6(15)$ \\
\hline HCG &
\end{tabular}

Table 2. Trends in clinical characteristics and chemotherapy regimens

\section{RPLA histology}

Studies of RP pathology demonstrated the presence of fibrosis in 15\%, teratoma in $39 \%$ and VC in $46 \%$, with survival in $67 \%, 56 \%$ and $32 \%$, respectively. Worse (VC) vs. favorable (fibrosis/teratoma) histology occurred in relation of $54 \%$ vs. $46 \%(p<0.05)$. RPLA histology was not associated with the size of the RP mass. Different histology occurred in 5 of 13 patients (38\%) on redo-RPLA in comparison to previous RP histology, whereas 6 patients $(46 \%)$ are alive and free of disease (Table 3.).

\begin{tabular}{|c|c|c|c|}
\hline Histology & No. of patients & Died & Alive free of disease \\
\hline Fibrosis & $5(15 \%)$ & $2(33 \%)$ & $4(67 \%)$ \\
\hline Teratoma & $16(39 \%)$ & $7(44 \%)$ & $9(56 \%)$ \\
\hline Vital carcinoma & $19(46 \%)$ & $13(68 \%)$ & $\mathbf{6 ( 3 2 \% )}$ \\
\hline Total & $41(100 \%)$ & $22(54 \%)$ & $19(46 \%)$ \\
\hline
\end{tabular}

Table 3. Clinical outcam in relation to histological analysis on salvage RPLA

\section{ERP sites of resection}

VC was indentified in 6 patients (55\%), teratoma in 2 patients $(18 \%)$ and fibrosis in 3 patients $(27 \%)$. Overall, 4 of 11 patients (36\%) had ERP specimen with the histologic finding as at the RPLA specimen, and 7 patients (64\%) had discordant histology (Table 4.)

EXTRA-RETROPERITONEAL HISTOLOGY, NO: OF PATINENTS(\%)

\begin{tabular}{|c|c|c|c|}
\hline RPLA HISTOLOGY & FIBROSIS & TERATOMA & $\mathbf{V C}$ \\
\hline FIBROSIS $(n=1)$ & $1(100)^{*}$ & - & - \\
\hline TERATOMA $(n=4)$ & $1(25)$ & - & $3(75)$ \\
\hline$V C(n=6)$ & $1(17)$ & $2(68)$ & $3(49)^{*}$ \\
\hline TOTAL $(n=11)$ & $3(27)$ & $2(18)$ & $6(55)$ \\
\hline
\end{tabular}

*concordinant histology

Table 4. Concordance of retroperitoneal and extra-retroperitoneal histology in 11 patinets 


\section{ORIGINALNI RADOVI}

\section{Clinical outcome}

Thirty patients (73\%) are rendered grossly free of disease and 26 (63\%) obtained serologic remission. Nine patients $(32 \%)$ who relapse within median free interval of 28 months

(8 in RP lymph nodes, 1 in RP lymph nodes and lung) necessitate new salvage chemotherapy followed by surgery ( 3 teratoma, $6 \mathrm{VC}$ ). Twenty two patients (54\%) died: 19 of primary disease, 2 of chemotherapy related toxicity and 1 of metachronous germ cell testicular tumor. Alive and free of disease are 19 patients (46\%) at median follow-up of 121 months (Table 5.).

Univariate analysis of clinicopathologic parameters associated with $\mathrm{VC}$ included RP mass $\geq 5 \mathrm{~cm}$ in diameter, elevated level of AFP $(p<0.001)$ or HCG $(p<0.05)$ and ERP resection $(p<0.04)$ (Table 6.).

\section{RPLA}

\section{CHARACTERISTICS}

NO: OF PATIENTS (\%)

\begin{tabular}{|l|l|}
\hline & 41 \\
\hline Rendered grossly free of disease & $30(73)$ \\
\hline Serologic remission & $26(63)$ \\
\hline Continously free of disease & $15(34)$ \\
\hline Relapse & $9(32)$ \\
\hline MFI to relapse, months (range) & $28(5-120)$ \\
\hline Localisation of relapse & RPLN(8), RPLN + lung (1) \\
\hline CR following surgery in relapse & $4(44)$ \\
\hline Died & $22(54)$ \\
\hline Alive free of disease & $19(46)$ \\
\hline MFU, months (range) & $131(49-225)$ \\
\hline
\end{tabular}

Table 5. Fate and survival following salvage

\begin{tabular}{|c|c|c|}
\hline VARIABLE & VC, NO. OF PATIENTS (\%) & $\underline{\mathbf{P}}$ \\
\hline \multicolumn{3}{|l|}{ Clinical stage } \\
\hline IIC & $10(50)$ & 0.4 \\
\hline III & $9(43)$ & \\
\hline \multicolumn{3}{|l|}{ IGCCCG category } \\
\hline Good $(n=13)$ & $7(54)$ & 0.9 \\
\hline Intermediate/poor(n=28) & $12(43)$ & \\
\hline \multicolumn{3}{|c|}{ Indication for 2nd line chemotherapy } \\
\hline Disease progression $(n=8)$ & $4(50)$ & 0.8 \\
\hline Disease recurrence $(n=10)$ & $3(30)$ & \\
\hline Residual disease $(n=23)$ & $12(52)$ & \\
\hline \multicolumn{3}{|c|}{ RP mass before salvage RPLA, $\mathrm{cm}$} \\
\hline$\geq 5(\mathrm{n}=30)$ & $15(50)$ & $<0.05$ \\
\hline$<5(n=11)$ & $4(37)$ & \\
\hline \multicolumn{3}{|l|}{ AFP elevated } \\
\hline Yes $(n=6)$ & $9(69)$ & $<0.001$ \\
\hline No $(n=28)$ & $10(36)$ & \\
\hline \multicolumn{3}{|l|}{ HCG elevated } \\
\hline Yes $(n=6)$ & $4(67)$ & $<0.05$ \\
\hline No $(n=35)$ & $14(43)$ & \\
\hline \multicolumn{3}{|c|}{ Extraretroperitoneal resection } \\
\hline Yes $(n=11)$ & $6(54)$ & $<0.04$ \\
\hline No $(n=30)$ & $13(43)$ & \\
\hline
\end{tabular}

Table 6. Univariante analysis of clinical pathological parameters and VC at the time of salvage RPLA 
On univariate analysis, survival was worse in patients who had RP mass $\geq 5 \mathrm{~cm}$ in diameters ( $<0.04)$, elevated level of AFP $(p<0.05)$ or HCG $(p<0.007)$, ERP resection $(p<0.001)$ and $\mathrm{VC}(\mathrm{p}<0.04)$.

On multivariable analysis, a RP mass $\geq 5 \mathrm{~cm}$ in diameter $(\mathrm{p}<0.005)$ and $\mathrm{VC}(\mathrm{p}<0.03)$ predicted worse prognosis. For a sensitivity of analysis, we excluded the patients who had elevated STM at the time of RPLA. VC either in RP or in ERP sites predicted worse prognosis $(p=0.001)$. Although it was not statistically significant, there was trend toward improved survival in patients who had $\mathrm{RP}$ mass $<5 \mathrm{~cm}(\mathrm{p}=0.14)$ and in patients who had teratoma or fibrosis in the RP ( $\mathrm{p}=0.07)$ (Table 7.).

\begin{tabular}{|l|c|c|c|}
\hline VARIABLE & HR & $\mathbf{9 5 \%}$ Cl & $\mathbf{p}$ \\
\hline $\begin{array}{l}\text { Worst histology of RP or extra-RP resection } \\
\text { (VC vs teratoma or fibrosis) }\end{array}$ & 4.42 & $1.6-12.4$ & 0.005 \\
\hline Size of RP mass pre RPLA $(\mathbf{5} \mathbf{~ v s ~}<\mathbf{5 c m})$ & 3.02 & $1.1-8.1$ & 0.03 \\
\hline Elevated HCG & 2.89 & $0.9-10$ & 0.08 \\
\hline
\end{tabular}

Table 7. Cox proportional hazards regression analysis for survival

\section{Discussion}

Resection of residual masses after multiple chemotherapy regimens is an integral component of the successful treatment of patients with advance NSTT ${ }^{9}$. The histologic findings after multiple chemotherapy regimens differ substantially from those generally reported for RPLA after induction chemotherapy, in which approximately $40 \%$ to $45 \%$ of patients have fibrosis, $40 \%$ to $45 \%$ of patients have teratoma, and $10 \%$ to $20 \%$ have $\mathrm{VC}^{9,10}$. For RPLA after multiple chemotherapy regimens, the largest series of patients, which was reported by Fox et $\mathrm{al}^{5}$, had $55 \%$ with $\mathrm{VC}$, constant with 2 subsequent studies by Hendry et $\mathrm{al}^{6}$ and Rick et al ${ }^{7}$, which showed rates of $42 \%$ and $49 \%$, respectively.

In the current study, there were three important findings for patients undergoing RPLA after multiple chemotherapy regimens. First, nearly $85 \%$ patients have either VC or teratoma.

Second, ERP disease frequently harbors VC or teratoma (73\%). Third, DSS is unfavorable (46\%).

Eggener et al in 2007 reported that the patients who received taxane-containing salvage regimens had a higher rate of fibrosis (51\%) and lower rate of VC (28\%) with CR in 70\% patients who received TIP (taxanes,ifosfamide,platinum) and in 57\% of patients who received TICE (taxanes, ifosfamide, carbolatin, etoposide) ${ }^{11}$. The 10 -year DSS rate was $70 \%$. Although it was lower, the frequency of VC confirm the important therapeutic role of salvage surgery while predicting the need for additional chemotherapy. The TIP regimen is administrated to patients who developed recurrent disease after achieving a CR to induction chemotherapy $^{2}$, whereas TICE is administrated after incomplete response to induction chemotherapy 4 .

In addition, nearly $39 \%$ of all patients in our study had elements of teratoma at RPLA. Considerable evidence highlights the importance of complete resection of teratoma. Residual teratoma has the potential for local growth, leading to local invasion and the growing syndrome ${ }^{12}$. Malignant transformation to sarcoma and various other histology has been reported ${ }^{13,14}$. Finally, patients with teratoma are at risk for late recurrence, which carries an increased probability of being refractory to treatment ${ }^{15,16,17,18}$.

Elements of VC or teratoma were indentified in $73 \%$ of patients who underwent ERP resection in comparison to only $31 \%$ in series of patients managed with taxane-containing regimens ${ }^{11}$. This study highlights the importance of resection of all sites of disease after chemotherapy, including ERP masses, to optimize outcome. Although there is an inherent appeal to determine the need for ERP resection on RP histology we observed an overall of $64 \%$ discordance rate between RP and ERP histology, in comparison of $25 \%$ in previously mentioned study ${ }^{11}$. Although patients with fibrosis in the RP had a high likelihood of fibrosis at ERP sites, the number of patients is small, and RP histology is not know when ERP resection are performed during the same surgery. Hence, without complete certainly regarding fibrosis at ERP sites, we continue to advocate resection of all ERP sites $^{16}$.

We also found a trend toward worse survival when the HCG level was increased prior to surgery, whereas the AFP level was not associated with worse outcome. These findings are consistent with previous reports 
that an elevated AFP level at time of salvage surgery is associated with a more favorable outcome compared with patients who have an elevated $\mathrm{HCG}^{19,20}$.

\section{Conclusions}

In a series of 41 patients who underwent RPLA after multiple chemotherapy regimens DSS can reach only $46 \%$, with finding of fibrosis in $15 \%$, teratoma in $39 \%$ and VC in $46 \%$ patients following conventional salvage chemotherapeutical regimens. During the latter years, taxanes-containing regimens resulted in significantly lower incidence of VC and higher incidence of fibrosis within resected specimen at RPLA, with 10-year DSS rate of 70\%. Therefore, TIP and TICE are salvage regimens of choice following relapse or incomplete response to $1^{\text {st }}$-line chemotherapy. On the other hand, our data support the continued use of salvage surgery in three separate groups of patients. First, patients who achieve a CR to $2^{\text {nd }}$-line chemotherapy and have no radiologic evidence of disease should undergo RPLA. Second, patients who achieve a PR to chemotherapy with resectable residual masses should undergo RPLA with ERP resection, as indicated. Finally, highly selected patients with residual masses and elevated STM levels, particularly AFP, after chemotherapy may be candidates for surgery.

\section{Literature}

1. Bosl GJ, Motzer RJ. Testicular germ cell cancer. N Engl J Med 1997; 337: 242-253.

2. Kondagunta GV, Bacik J, Donadio A. Combination of paclitaxel, ifosfamide and cisplatin is and effective secondline chemotherapy for patients with relapsed testicular germ cell tumors. J Clin Oncol 2006: 23: 6549-6555.

3. McCaffrey JA, Masumdar M, Bajorin DF. Ifosfamide- and cisplatin-containing chemotherapy as first-line salvage therapy in germ cell tumors: response and survival. J Clin Oncol 1997; 15: 2559-2563.

4. Motzer RJ, Masumdar M, Sheinfeld J. Sequential dose -intensive paclitaxel, ifosfamide, carboplatin, and etoposide salvage therapy for germ cell tumor patients. J Clin Oncol 2000; 18: 1173-1180.

5. Fox EP, Weathers TD, Williams SD. Outcome analysis for patients with persistent nonteratomatous germ cell tumor in postchemotherapy retroperitoneal lymph node dissection. J Clin Oncol 1993; 11: 1294-1299.

6. Hendry WF, Norman AR, Dearnaley DP. Metastatic nonseminomatous germ cell tumors of the testis: results of effective and salvage surgery for patients with residual retroperitoneal masses. Cancer 2002; 94: 1668-1676.

7. Rick O, Bokemeyer C, Weinknecht S. Residual tumor resection after high-dose chemotherapy in patients with relapsed or refractory germ cell cancer. J Clin Oncol 2004; 22: 3713-3719.

8. International Germ Cell Cancer Collaborative Group. International Germ Cell Concensus Classification: a prognostic factor-based staging system for metastatic germ cell cancers. J Clin Oncol 1997: 15: 594-603.

9. Donohue JP, Leivovitch I, Foster RS. Integration of surgery and systemic therapy: results and principles of integration. Sem in Urol Oncol 1998; 16: 65-71.

10. Donohue R, Rowland RG: The role of surgery in advanced testicular cancer. Cancer 1984; 54 (11 Suppl): 2716-2721.

11. Eggener SE, Carver BS, Loeh S. Pathologic and clinical outcomes of patients undergoing retroperitoneal lymph node dissection after multiple chemotherapy for metastatic testicular germ cell tumors. Cancer 2007; 109: 528-535.

12. Steyeberg EW, Gerl A, Fossa SD. Validity of predictions of residual retroperitoneal mass histology in nonseminomatous testicular cancer. J Clin Oncol 1998; 16: 239-274.

13. Logothetis CJ, Samuels ML, Trindade A, Johnson DE. The growing teratoma syndrome. Cancer 1982; 50: 1629-1635.

14. Motzer RJ, Amsterdam AP, Pineto V. Teratoma with malignant transformation: diverse malignant histologies arising in men with germ cell tumors. J Urol 1998; 159: 133-138.

15. Argirovic D, Argirovic A, Stanic V. Long-term outcome after postchemotherapy retroperitoneal lymphadenectomy in patients with residual teratoma. Eur Urol ( Suppl 8) 2009: 586: 596. 
16. Argirovic D, Stanic V, Argirovic A. The impact of residual extra-retroperitoneal masses in patients with advanced nonseminomatous testicular tumors. Eur Urol (Suppl 8) 2009; 625: 553.

17. Argirovic D: Late relapses of germ cell testicular tumours: A population based experience over 23 years. Eur Urol Meet 2007; 2 (5): 38.

18. Argirovic D. Late relapses of germ cell tumors following cisplatin-based chemotherapy. Eur Urol Meet 2007; 2(7): 138.

19. Beck SD, Patel MI, Sheinfeld J. Tumor marker levels in post-chemotherapy cystic masses: clinical implications for patients with germ cell tumors. J Urol 2004; 171: 168-171.

20. Murphy BR, Breeden ES, Dlonohue JP. Surgical salvage of chemorefractory germ cell tumors. J Clin Oncol 1993; 11: 324-329.

Correspondance to: Djordje Argirovic

Outpatient Clinic „Argirovic“, Urology

11.080 Belgrade

Cvijiceva $84 \mathrm{~A}$

Tel.:+381 112788498

Fax.:+ 381113290324

E-mail:cvijiceva@yubc.net 